\title{
Assessment of Physical and Mechanical Properties of Concrete Produced from Various Portland Cement Brands
}

\author{
Asal Soltani' ${ }^{1}$, Salim Khoso', Manthar Ali Keerio ${ }^{2}$, Antonio Formisano ${ }^{3}$ \\ ${ }^{1}$ Department of Civil and Environmental Engineering, The University of Toledo, Toledo Ohio, USA \\ ${ }^{2}$ Department of Civil Engineering, Quaid-e-Awam University College of Engineering, Sciences \& Technology (QUCEST), \\ Larkana, Sindh, Pakistan \\ ${ }^{3}$ Department of Structures for Engineering and Architecture, School of Polytechnic and Basic Sciences, University of Naples \\ "Federico II", Naples, Italy \\ Email: Asal.soltani@rockets.utoledo.edu,Salim.khoso@rockets.utoledo.edu,mantharali99@quest.edu.pk, antoform@unina.it
}

How to cite this paper: Soltani, A., Khoso, S., Keerio, M.A. and Formisano, A. (2019) Assessment of Physical and Mechanical Properties of Concrete Produced from Various Portland Cement Brands. Open Journal of Composite Materials, 9, 327-337. https://doi.org/10.4236/ojcm.2019.94020

Received: February 19, 2019

Accepted: September 21, 2019

Published: September 24, 2019

Copyright (c) 2019 by author(s) and Scientific Research Publishing Inc. This work is licensed under the Creative Commons Attribution International License (CC BY 4.0).

http://creativecommons.org/licenses/by/4.0/

\begin{abstract}
Construction projects require cement, which must have definite qualities so as to play its part separately in structure. The compressive strength of cement and, consequently, its physical properties could vary as a result of variations in the raw materials, as well as in manufacturing conditions. Therefore, an experimental study has been checked out herein by investigating the mechanical and physical properties of concrete specimens by means of four different types of Ordinary Portland Cements, namely Black Bull, Lucky, Pak Land and DG obtained from the market of Sindh Pakistan. Based on obtained results, it was found that Lucky cement type performed well when compared to other three types both in compressive and tensile strength of concrete. Although there were some differences in the physical properties of cement used in this study, however, they all meet with the requirements of international standards.
\end{abstract}

\section{Keywords}

Cement, Brands, Concrete, Compressive Strength, Tensile Strength

\section{Introduction}

Before the separation of sub-continent, cement industry was one of the few industries that existed in Pakistan. The main reason for the existence of this industry was the accessibility to the available raw materials required to make cement. Pakistan has been blessed with vast reserves of limestone and clay and, 
which can support the cement industry for upcoming 5 to 6 decades. At the time of creation of Pakistan, the production of cement per annum was only about 0.3 million tons. However, by the year 1954 the cement production increased to 0.66 million tons annually against a yearly demand of 1.0 million tons. At present many cement factories have been established, thus increasing the production to 1.0 million tons per year. Since then, along with the extension of the existing plants, new plants have also been established. Besides producing Ordinary Portland Cement (OPC), the cement industries in Pakistan have also started to produce Slag cement, SRC, and white cement [1], [2], [3]. Cement production has played a major role as a material of construction throughout the history of civilization. It has a significant value in the construction of buildings, tunnels, bridges, highways, towers and so on [4], [5]. The cement used in various projects must have certain qualities in order to play its part electively in structures. Engineers become more satisfied and confident, thereby guarantying a good quality work, if these properties lie within a certain specified range of standard values [6], [7], [8]. Furthermore, based on these properties, it is possible to compare the cement quality from different sources. Numerous tests are conducted in the laboratories of cement industries in order to ensure that the cement is of the desired quality and it obeys the rules and regulations recommended by relevant codes and standards [9], [10], [11]. Utilization of lower quality cement in construction projects may cause loss of precious lives and properties. Thus, the assessment of cement quality is of a significant and critical factor. During this research study, four brands of Portland cement products (Black Bull, Pak Land, Lucky and DG) available in the market of Sindh province have been studied for assessing experimentally the compressive and tensile strengths. The results obtained for all the analysis showed that few types of cement are better than the others. Indeed, Ordinary Portland cement is the general cement found in numerous countries and it is manufactured by different companies. Therefore, this research activity aims to compare the properties of Portland cements in Sindh Province. Laboratory-based experimental approach was adopted in this study to determine the properties of four cement samples as mentioned above. It was observed that Lucky cement has the finest particles containing more Calcium oxide $(\mathrm{CaO})$, recording earlier setting times and achieving early strength. The research work has revealed that, although there are some differences in the properties of four cement types used, they all meet international standard requirements. In fact, the importance of using appropriate cement types represents a research activity very felt in Pakistan, where other similar studies were performed [12] [13] [14] [15] [16]. This represents a very important result, considering that both the quality assurance of cement is becoming a construction critical factor and the use of lower quality cement in structural and constructional projects may result in poor structures causing loss of lives and properties.

\section{Basic Chemistry of Ordinary Portland Cement}

For manufacturing Ordinary Portland Cement (OPC), natural stones such as 
Limestone, shale or clay are brought from quarries to the cement industry. The major constituents of obtained rocks are Lime $\left(\mathrm{CaCO}_{3}\right)$, Silica $\left(\mathrm{SiO}_{2}\right)$, Alumina $\left(\mathrm{Al}_{2} \mathrm{O}_{3}\right)$, and Iron Oxide $\left(\mathrm{Fe}_{2} \mathrm{O}_{3}\right)$. These compounds are brought in kiln and are heated at temperature about $1250^{\circ} \mathrm{C}$ to $1450^{\circ} \mathrm{C}$ where they interrelate to form a series of more complex products. During the formation of various compounds, some chemical reactions take place within the burning mass which results in forming clinkers and cement materials. Clinkers play a vital role in the final product of cement, which contains compounds like $\mathrm{K}_{2} \mathrm{O}, \mathrm{TiO}_{2}, \mathrm{MnO}_{2}$, and $\mathrm{Na}_{2} \mathrm{O}$. Other than these, the major mineral constituents of cement clinker are listed in Table 1.

\section{Materials and Methodology}

\subsection{Materials}

Materials used during this experimental work are mainly cement, sand, coarse aggregate and water. Four different types of Ordinary Portland cements, i.e. Lucky, Black bull, DG and Pak Land, were purchased from the local market. Care was taken not to buy outdated cements and the manufacture date of cement was not more than 20 days from the time it was produced. Locally available clean natural hill sand passing from $4.75 \mathrm{~mm}$ sieve free from clay was used. Coarse aggregate having maximum size of $19 \mathrm{~mm}$ clean and free from other ingredients was incorporated in preparing cement concrete mix. Whereas potable water having $\mathrm{pH}$ value of 7.1 taken from the tap of Structural Engineering Laboratory at the Department of Civil Engineering of the Quaid-e-Awam University, College of Engineering, Science and Technology (QUCEST), Larkano, Sindh, Pakistan, was used in all mixtures.

\subsection{Methodology}

In total 90 specimens of different concrete mixtures based on the four mentioned cement types were cast. Cement concrete mix of 1:2:4 ratio (water-to-cement ratio of 0.45) was used during this research work [18] [19] [20] [21]. Mixing of concrete was done using in a mechanical mixer having capacity of 6 cubic feet. For each mixture and for three curing periods $(7,14$ and 28 days), 15 cubes with sides of $150 \mathrm{~mm}$ were prepared, so resulting in a total

Table 1. Typical composition of mineral constituents found in Portland cement clinker [17].

\begin{tabular}{cccc}
\hline S. No. & Compound & Chemical Formula & Abbreviated Designation \\
\hline 1 & Tricalcium aluminate & $\mathrm{Ca}_{3} \mathrm{Al}_{2} \mathrm{O}_{6}$ & $\mathrm{C}_{3} \mathrm{~A}$ \\
2 & Tetracalcium aluminoferrite & $\mathrm{Ca}_{4} \mathrm{Al}_{2} \mathrm{Fe}_{2} \mathrm{O}_{10}$ & $\mathrm{C}_{4} \mathrm{AF}$ \\
2 & dicalcium silicate & $\mathrm{Ca}_{2} \mathrm{SiO}_{5}$ & $\mathrm{C}_{2} \mathrm{~S}$ \\
4 & tricalcium silicate & $\mathrm{Ca}_{3} \mathrm{SiO}_{4}$ & $\mathrm{C}_{3} \mathrm{~S}$ \\
5 & Gypsum & $\mathrm{CaSO}_{4} \cdot 2 \mathrm{H}_{2} \mathrm{O}$ & $\mathrm{CSH}_{2}$ \\
\hline
\end{tabular}


number of 45 cubes, which were cast to check the compressive strength. Similarly, for each mixture and for the three above curing periods, 15 cylinders having diameter of $150 \mathrm{~mm}$ and height of $300 \mathrm{~mm}$ were cast to check the spilt tensile strength of concrete. The specimens were fabricated and removed from moulds after 24 hours and kept in a totally wet environment for 7, 14 and 28 days curing period [22] [23] [24] [25].

\section{Results and Discussions}

\subsection{Workability Test}

Workability test for all cement brands used during this research work was conducted in accordance to the ASTM standards C-192 [26]. Slump cone was used for all the prepared concrete mixes and the slump test results of all the different concrete brands are given in Table 2. There is no remarkable difference in the workability of all the cement brands used. Therefore, it may be concluded that the difference in the workability is minimal.

\subsection{Compressive Strength of Concrete}

Compressive strength test was conducted using Forney load testing machine and the procedure was conducted in accordance to the ASTM C39/C39M - 18 [27]. Results of compression tests on cubes at 7, 14 and 28 days curing period using four different types of cement (Black Bull, Pak land, Lucky and DG cements) are given in Figure 1.

The average values deriving from experimental compression tests are observed in Figure 2.

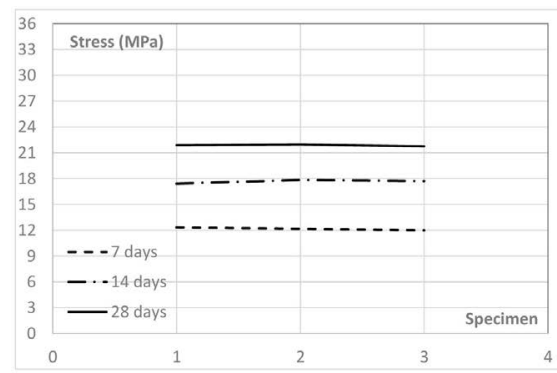

(a)

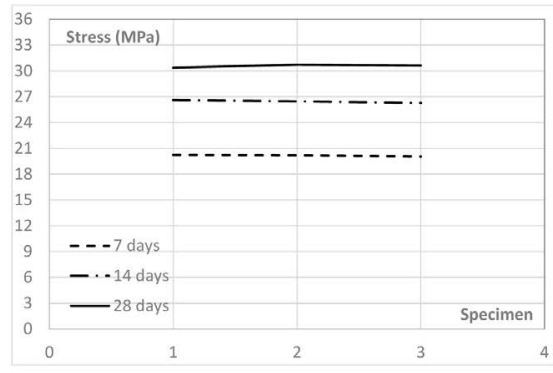

(c)

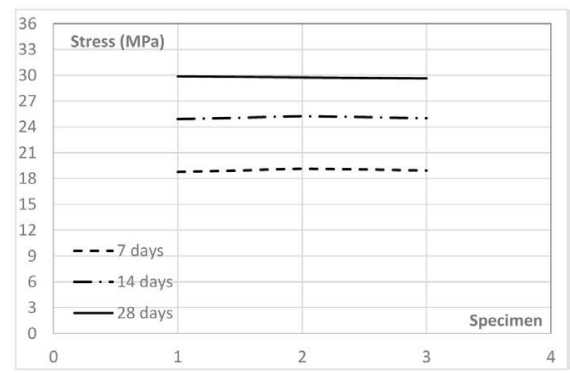

(b)

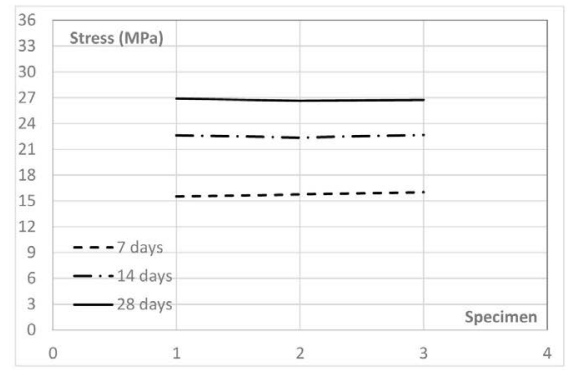

(d)

Figure 1. Results of experimental compression tests on specimens made of Black Bull (a); Pak land (b); Lucky (c) and DG (d) cements. 


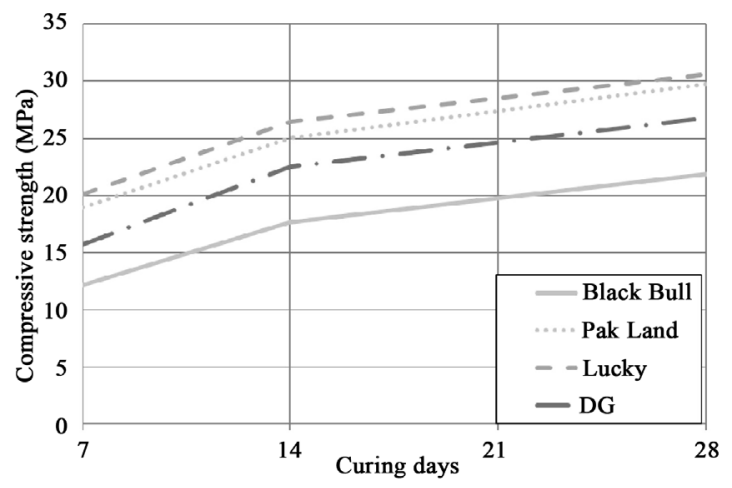

Figure 2. Average compressive strength of cubes at curing period of 7, 14 and 28 days.

Table 2. Workability test results of concrete mixes prepared with different cement brands.

\begin{tabular}{ccccc}
\hline S. No. & Cement Brand & W/c Ratio & Mix Design Ratio & Slump (in.) \\
\hline 1 & Black Bull & 0.45 & $1: 02: 04$ & 2.05 \\
2 & Pak Land & 0.45 & $1: 02: 04$ & 2.02 \\
3 & Lucky & 0.45 & $1: 02: 04$ & 1.96 \\
4 & DG & 0.45 & $1: 02: 04$ & 1.98 \\
\hline
\end{tabular}

It can be observed from Figure 2 that there is a clear variation in the compressive strength test results of all the cement types used. The peak values of the cube compressive strength are obtained from the concrete specimen made with Lucky cement. Subsequently, Pak land cement concrete gave the most considerable compressive strength. Finally, the strengths achieved by DG Cement and Black bull are gradually decreasing.

Finally, on the basis of the obtained results, forecast of the concrete compression strength at a given curing time $(7<t \leq 28)$ can be done starting from that at 7 days through the following relationship:

$$
f_{c, t}=f_{c, 7}+t^{0.65} \quad(7<t \leq 28)
$$

where:

$f_{c, t}=$ concrete compression strength after a curing time $t$ from 8 to 28 days;

$f_{G, 7}=$ concrete compression strength after a curing time $t=7$ days;

$t=$ curing period variable from 8 to 28 days.

Equation (1) provides concrete compression resistances on the safe side with respect to experimental values, as shown in the comparison graph of Figure 3, where a maximum experimental-theoretical scatter of about $8 \%$ is noticed (see Table 3). This confirms the reliability of the equation found to predict the concrete compression strength with the curing time.

\subsection{Tensile Strength of Concrete}

Split tensile strength was conducted for all cylinders in accordance to ASTM C496/C496M-17 standards [28]. Results of split tensile strength on cylinders 


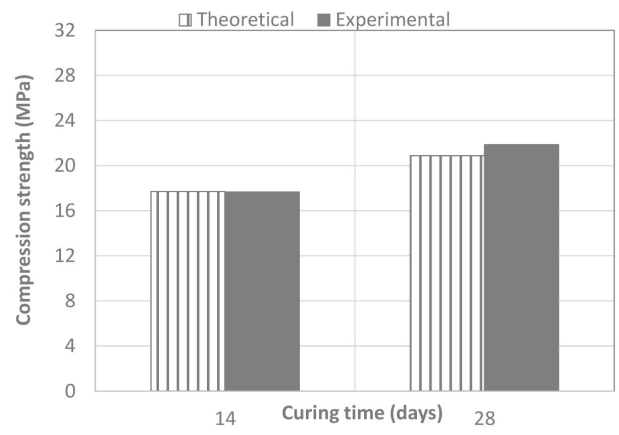

(a)

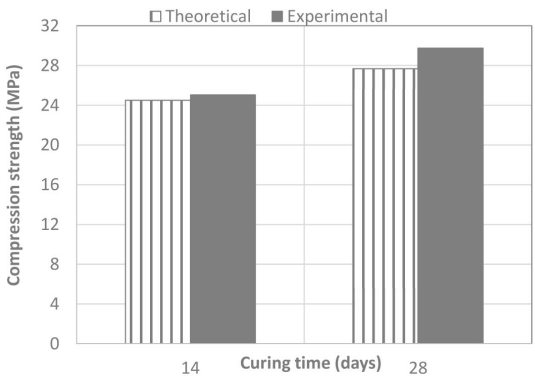

(b)

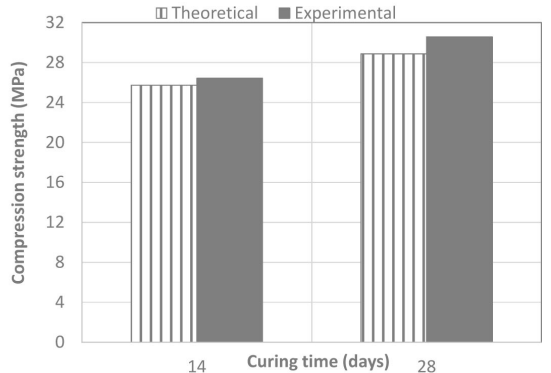

(c)

Figure 3. Comparison between theoretical and experimental compression strength average values for concrete specimens made of black bull (a); Pak land (b); Lucky (c) and DG (d) cements.

Table 3. Experimental-theoretical comparison among compression strength values for the tested concrete cubes.

\begin{tabular}{ccccccc}
\hline \multirow{2}{*}{$\begin{array}{c}\text { Type of } \\
\text { cement }\end{array}$} & $\begin{array}{c}\text { Experimental } \\
(\mathrm{MPa})\end{array}$ & $\begin{array}{c}\text { Theoretical } \\
(\mathrm{MPa})\end{array}$ & $\begin{array}{c}\text { Scatter } \\
\%\end{array}$ & $\begin{array}{c}\text { Experimental } \\
(\mathrm{MPa})\end{array}$ & $\begin{array}{c}\text { Theoretical } \\
(\mathrm{MPa})\end{array}$ & $\begin{array}{c}\text { Scatter } \\
\%\end{array}$ \\
\hline Black Bull & 17.65 & 17.71 & $/$ & 21.86 & 20.87 & 4 \\
Pak Land & 25.05 & 24.5 & 2 & 29.75 & 27.66 & 7 \\
Lucky & 26.44 & 25.71 & 3 & 30.58 & 28.87 & 6 \\
DG & 22.55 & 21.32 & 5 & 26.76 & 24.48 & 8 \\
\hline
\end{tabular}

made of four different types of cement at curing times of 7, 14 and 28 days are shown in Figure 4. For these tests the tensile strengths have a variability greater than that deriving from compression test strength values. The average tensile strengths are illustrated in Figure 5.

It may be observed from Figure 5 that the cylinder specimens cast by using Lucky cement revealed the highest tensile strength. However, on the other hand, less performance is achieved by Black bull cement as compared to Lucky cement.

Finally, on the basis of the obtained results, forecast of the concrete tensile strength at a given curing time $(7 \leq t \leq 28)$ can be simply done starting from the corresponding compression strength value through the following relationship:

$$
f_{c, t t}=0.10 \times f_{c, c t}(7 \leq t \leq 28)
$$




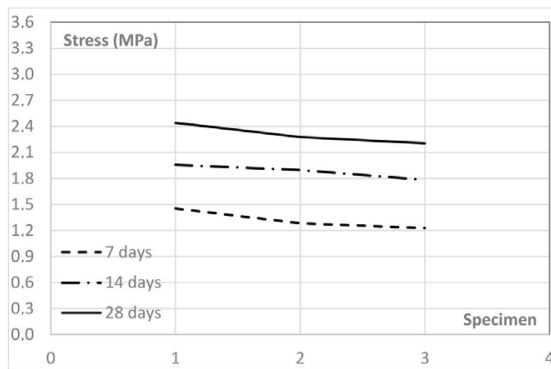

(a)

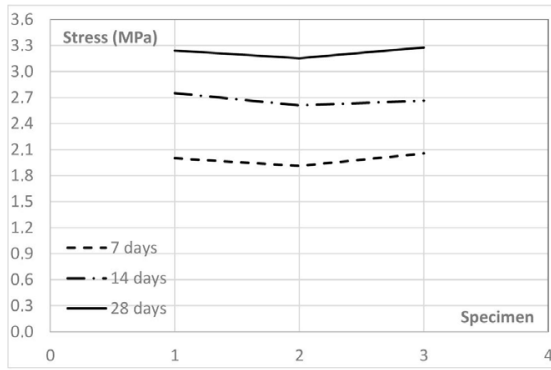

(c)

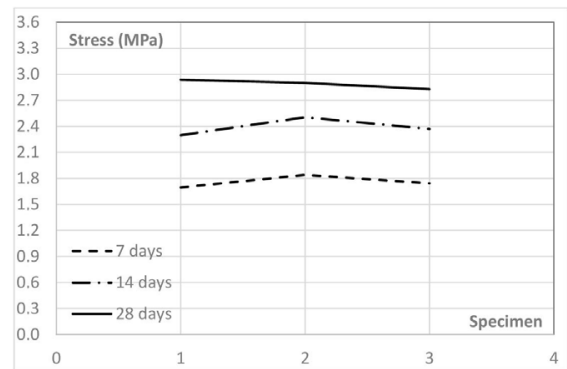

(b)

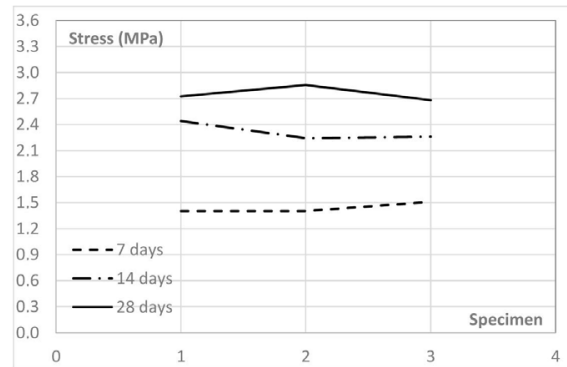

(d)

Figure 4. Results of experimental tensile tests on specimens made of (a) Black bull; (b) Pak land; (c) Lucky and (d) DG cement brands.

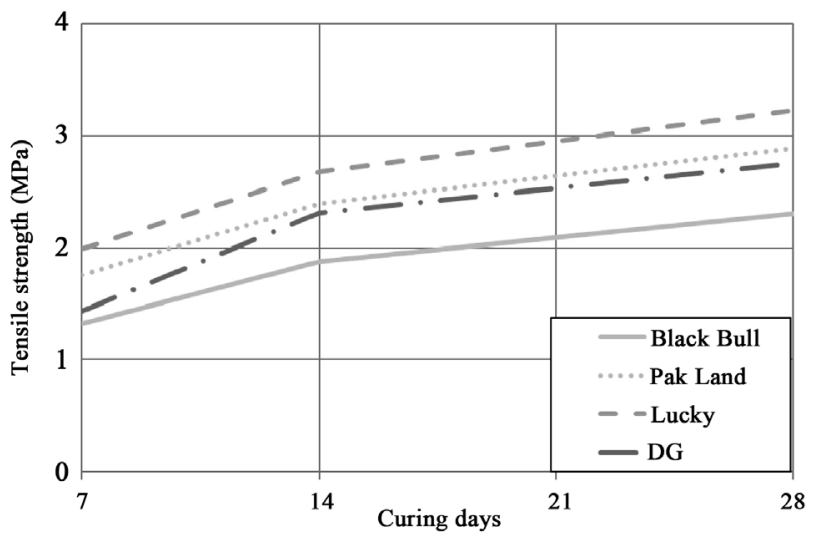

Figure 5. Split tensile strengths of cylinders at curing period of 7, 14 and 28 days.

where:

$f_{c, t t}=$ concrete tensile strength after a curing time $t$ from 7 to 28 days;

$f_{c, c t}=$ concrete compression strength after a curing time $t$ from 7 to 28 days.

Equation (2) provides concrete tensile resistances not always on the safe side with respect to experimental values, as shown in the comparison graph of Figure 6. In particular, as shown more in detail in Table 4, the prediction formula overestimates the strength of concretes with curing time of 7 days made of Pak Land (also at 14 days), Lucky and DG cements with maximum experimental-theoretical scatters from $1 \%$ to $10 \%$. This is due to the larger variability of tensile strength results in comparison to those deriving from compression tests. However, the prediction formula seems to be quite good, since the detected scatters are limited. 
Table 4. Experimental-theoretical comparison among tensile strength values for the tested concrete cubes.

\begin{tabular}{|c|c|c|c|c|c|c|c|c|c|}
\hline \multirow{2}{*}{$\begin{array}{l}\text { Type of } \\
\text { cement }\end{array}$} & \multicolumn{3}{|c|}{7 days } & \multicolumn{3}{|c|}{14 days } & \multicolumn{3}{|c|}{28 days } \\
\hline & $\begin{array}{l}\text { Experimental } \\
\text { (MPa) }\end{array}$ & $\begin{array}{c}\text { Theoretical } \\
\text { (MPa) }\end{array}$ & $\begin{array}{l}\text { Scatter } \\
\%\end{array}$ & $\begin{array}{c}\text { Experimental } \\
\text { (MPa) }\end{array}$ & $\begin{array}{c}\text { Theoretical } \\
\text { (MPa) }\end{array}$ & $\begin{array}{c}\text { Scatter } \\
(\%)\end{array}$ & $\begin{array}{c}\text { Experimental } \\
(\mathrm{MPa})\end{array}$ & $\begin{array}{c}\text { Theoretical } \\
\text { (MPa) }\end{array}$ & $\begin{array}{l}\text { Scatter } \\
\%\end{array}$ \\
\hline Black Bull & 1.32 & 1.21 & -8 & 1.88 & 1.77 & -6 & 2.31 & 2.09 & -9 \\
\hline Pak Land & 1.76 & 1.89 & 8 & 2.39 & 2.45 & 3 & 2.89 & 2.77 & -4 \\
\hline Lucky & 1.99 & 2.02 & 1 & 2.68 & 2.57 & -4 & 3.22 & 2.89 & -10 \\
\hline DG & 1.44 & 1.58 & 10 & 2.31 & 2.13 & -8 & 2.75 & 2.45 & -11 \\
\hline
\end{tabular}

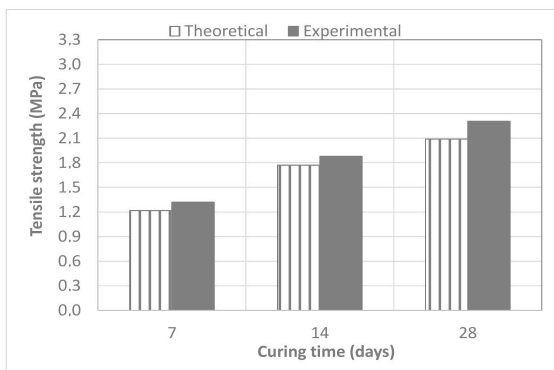

(a)

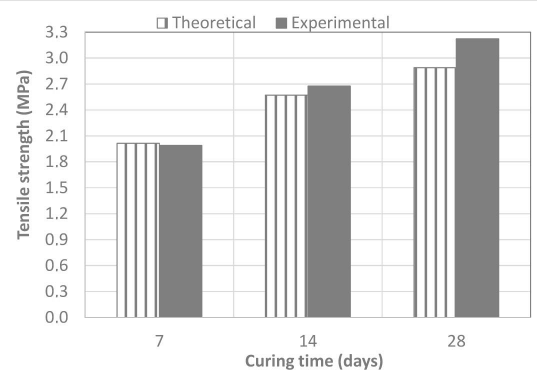

(c)

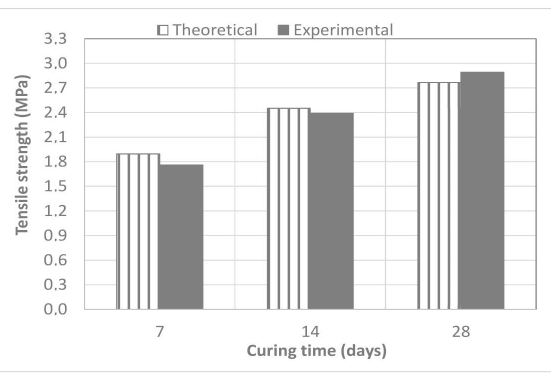

(b)

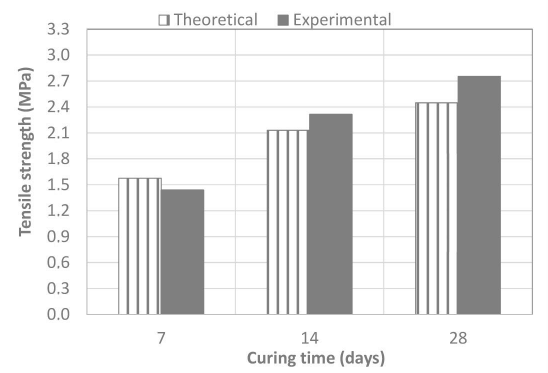

(d)

Figure 6. Comparison between theoretical and experimental tensile strength average values for concrete specimens made of (a) Black bull; (b) Pak land; (c) Lucky and (d) DG cement brands.

Moreover, simple relationships have been found to predict the tensile strength of concrete at a given curing time $t$ (14 or 28 days) starting from that achieved after 7-days maturation as follows:

$$
\begin{aligned}
& f_{c, t 14}=f_{c, t 7}+0.2 \times \ln (t) \text { for } t=14 \text { days } \\
& f_{c, t 28}=f_{c, t 7}+0.3 \times \ln (t) \text { for } t=28 \text { days }
\end{aligned}
$$

where:

$f_{c, t}=$ concrete tensile strength after a curing time $t$ of 7 days;

$f_{c, t 14}=$ concrete tensile strength after a curing time $t$ of 14 days;

$f_{c, 28}=$ concrete tensile strength after a curing time $t$ of 28 days.

The effectiveness of the above formulas is proved by the comparison between experimental values and theoretical ones shown in Table 5, where it is apparent that both prediction strengths are almost always less than experimental ones and scatters are within the range $[-9 \%,+1 \%]$. 
Table 5. Experimental-theoretical comparison among tensile strength values for the tested concrete cubes.

\begin{tabular}{ccccccc}
\hline \multirow{2}{*}{$\begin{array}{c}\text { Type of } \\
\text { cement }\end{array}$} & $\begin{array}{c}\text { Experimental } \\
(\mathrm{MPa})\end{array}$ & $\begin{array}{c}\text { Theoretical } \\
(\mathrm{MPa})\end{array}$ & $\begin{array}{c}\text { Scatter } \\
(\%)\end{array}$ & $\begin{array}{c}\text { Experimental } \\
(\mathrm{MPa})\end{array}$ & $\begin{array}{c}\text { Theoretical } \\
(\mathrm{MPa})\end{array}$ & $\begin{array}{c}\text { Scatter } \\
(\%)\end{array}$ \\
\hline Black Bull & 1.88 & 1.74 & -7 & 2.31 & 2.21 & -4 \\
Pak Land & 2.39 & 2.42 & 1 & 2.89 & 2.89 & $/$ \\
Lucky & 2.68 & 2.54 & -5 & 3.22 & 3.01 & -4 \\
DG & 2.31 & 2.1 & -9 & 2.75 & 2.58 & -6 \\
\hline
\end{tabular}

\section{Conclusions}

This research work compares the compressive and tensile strength test results of four different cement types available in the market of Sindh province. On the basis of compressive and tensile strengths of concrete using four cement types, namely Black Bull, Pak Land, Lucky and DG, it could be concluded that:

1) The lucky cement gave the maximum compressive strength and the obtained peak value was about $31 \mathrm{MPa}$ after a curing period of 28 days and could be considered for constructing all kind of structures.

2) Maximum tensile strength is also obtained when the concrete specimens are made of Lucky cement. The peak value obtained for cylinders is $3.22 \mathrm{MPa}$ for the curing time of 28 days.

3) The compressive strengths obtained from the remaining three cement types, i.e. Pak land, DG and Black Bull, are 29.75 MPa, 26.76 MPa and 21.86 $\mathrm{MPa}$, respectively, for the maximum curing period of 28 days.

4) Split tensile strength test results obtained from the remaining three cement types (Pak land, DG and Black Bull) revealed strengths equal to $2.8 \mathrm{MPa}, 2.75$ $\mathrm{MPa}$ and $2.31 \mathrm{MPa}$, respectively, for the curing period of 28 days.

5) By comparing all obtained test results and the different curing periods of 7 , 14 and 28 days, the brand labeled Lucky cement performed better among all four types of cements used in this work. On the other hand, remaining three cement brands revealed little less strength, however, still meeting with the International standards.

6) Simple polynomial and natural logarithmic functions have been found to predict on the safe side the concrete compression strengths and tensile ones, respectively.

Finally, the above results demonstrated the reliability of the study carried out, even if additional tests should be performed in order to have also a statistical distribution of strengths to predict in better way the resistance of concrete specimens made of the different cement brands investigated.

\section{Acknowledgements}

The details of the research activity given in this article were carried out in the structural engineering laboratory of Department of Civil Engineering at 
(QUCEST), Larkana, Sindh, Pakistan. The authors appreciate the efforts and dedication of the student of $12 \mathrm{CE}$ batch in bringing the cement types used and to conduct tests eventually making this research work possible. The funding to carry this research work was done by the authors themselves along with some part from the students of $12 \mathrm{CE}$ batch.

\section{Conflicts of Interest}

The authors declare no conflicts of interest regarding the publication of this paper.

\section{References}

[1] Ravi Magazine (2015) Analysis of Pakistani Cement Industry-A Report. http://www.ravimagazine.com/analysis-of-pakistani-cement-industry-a-report

[2] Shreves, A.G. (1985) Chemical Process Industries. McGraw Hill Book Company, Singapore.

[3] Ali, K., Amin, N. and Shah, M. (2009) Physicochemical Study of Bagasse and Bagasse Ash from the Sugar Industries of NWFP Pakistan and Its Recycling in Cement Manufacturing. Journal of the Chemical Society of Pakistan, 31, 375-378.

[4] Amin, N., Ali, K. and Shah, M. (2009) Recycling of Bagasse Ash in Cement Manufacturing and Its Impact on Clinker Potential and Environmental Pollution. Journal of the Chemical Society of Pakistan, 31, 357-361.

[5] Amin and Ali (2010) Chemical Analysis and Comparison of Ordinary Portland Cement of Khyber Pakhtunkhwa Pakistan. Chemical Engineering Research Bulletin, 14, 45-49. https://doi.org/10.3329/cerb.v14i1.4320

[6] Falah, F.B.H. (2011) Chemical Analysis of Ordinary Portland Cement of Jordan. Assiut University Bulletin for Environmental Researches, 14, 56-62.

[7] Humphrey, D. and Isaac, B. (2015) Quality of Type I Portland Cement from Ghana and UK. Civil and Environmental Research, 7, 38-47.

[8] Khoso, S., Raad, J. and Parvin, A. (2019) Experimental Investigation on the Properties of Recycled Concrete Using Hybrid Fibers. Open Joural of Composite Materials, 9, 183-196. https://doi.org/10.4236/ojcm.2019.92009

[9] Faleye, F.J., Ogunnubi, S. and Olaofe, O. (2009) Chemical and Physical Analysis of Selected Cement Samples in Nigerian Market. Bangladesh Journal of Scientific and Industrial Research, 44, 41-50. https://doi.org/10.3329/bjsir.v44i1.2712

[10] Sajjad, A.M., Norwati, B.J., Zuhaib, S., Sheeraz, A.M. and Mohd, H.W.I. (2019) Utilization of Sawdust in Concrete Masonry Blocks: A Review. Mehran University Research Journal of Engineering \& Technology, 38, 487-494.

[11] Sajjad, A.M., Mohd, H.W.I., Norwati, J., Mohd, F.A. and Ramadhansyah, P.J. (2019) Short-Term Effects of Sulphate and Chloride on the Concrete Containing Coal Bottom Ash as Supplementary Cementitious Material. Engineering Science and technology, an International Journal, 22, 515-522. https://doi.org/10.1016/j.jestch.2018.09.001

[12] Sajjad, A.M., Mohd, H.W.I., Norwati, J., Mohd, F.A. and Sri, W.M. (2019) Recycling of Coal Ash in Concrete as a Partial Cementitious Resource. Multidisciplinary Digital Publishing Institute, Basel, 1-10.

[13] Amin, N., Ali, K. and Shah, M. (2008) Chemical Study of Limestone and Clay for Cement Manufacturing in Darukhula Nizampur, District Nowshera, N.W.F.P., Pa- 
kistan. Chinese Journal of Geochemistry, 27, 242-248. https://doi.org/10.1007/s11631-008-0242-8

[14] Haecker, C.J., Bentz, D.P., Feng, X.P. and Stutzman, P.E. (2003) Prediction of Cement Physical Properties by Virtual Testing. Cement International, 1, 86-92.

[15] Gao, Y. and Song, Z. (2013) The Influence on Cement Setting Time and Compression Strength by Adding Stannous Sulphate. Study of Civil Engineering and Architecture (SCEA), 2, 85-89.

[16] Sam, R.A., Bamford, S.A., Fletcher, J.J. and Ofosu, F.G.A. (2013) Assessment of Quality of the Various Brands of Portland Cement Products Available on the Ghanaian Market. International Journal of Science and Technology, 2, 252-258.

[17] Nabil, A.A.E., Mohamed, W.A.M., Hatem, M.D. and Atef, A.A. (2015) Characterization and Technological Behavior of Basalt Raw Materials for Portland Cement Clinker Production. International Journal of Innovative Science, Engineering \& Technology, 2.

[18] Khoso, S., Wagan, F.H., Khan, J.S., Bhatti, N.K. and Ansari, A.A. (2014) Qualitative Analysis of Baked Clay Bricks Available in Larkana Region, Pakistan. Journal of Architecture Civil Engineering Environment ACEE Poland, 7, 41-50.

[19] Khoso, S., Ansari, A.A. and Wagan, F.H. (2014) Investigative Construction of Buildings Using Baked Clay Post-Reinforced Beam Panels. Journal of Architecture Civil Engineering Environment ACEE Poland, 7, 57-66.

[20] Khoso, S., Ansari, A.A., Khan, J.S. and Wagan, F.H. (2015) Experimental Study on Recycled Concrete Using Dismantled Road Aggregate and Baggase Ash. Proceedings of 7 th International Civil Engineering Congress, Sustainable Developments through Advancements in Civil Engineering, Karachi, 54-61.

[21] Khoso, S., Khan, J.S., Ansari, A.A. and Khaskheli, Z.H. (2016) Experimental Investigation on the Properties of Cement Concrete Partially Replaced by Silica Fume and Fly Ash. International Journal of Applied Engineering Science, 14, 345-344. https://doi.org/10.5937/jaes14-11116

[22] Keerio, M.A., Khoso, S., Khan, J.S., Ansari, A.A. and Bhatti, N.K. (2017) The Effect of Waste Glass as Partial Replacement of Cement on Properties of Concrete. Engineering Science and Technology International Research Journal, 1, 59-63.

[23] Khoso, S., Keerio, M.A., Ansari, A.A., Khan, J.S. and Bangwar, D.K. (2017) Effect of Rice Husk Ash and Recycled Aggregates on Mechanical Properties of Concrete. International Journal of Scientific \& Engineering Research, 8, 1832-1835.

[24] Saand, A., Keerio, M.A., Juj, R., Khoso, S. and Bangwar, D.K. (2017) Utilization of Waste Glass as Partial Replacement of Fine Aggregate in Concrete. Engineering Science and Technology International Research Journal, 1, 28-31.

[25] Khoso, S., Naqash, M.T., Sher, S. and Saeed, Z. (2018) An Experimental Study on Fiberly Reinforced Concrete Using Polypropylene Fibre with Virgin and Recycled Road Aggregate. Journal of Architecture Civil Engineering Environment ACEE, Poland, 11, 73-80. https://doi.org/10.21307/ACEE-2018-007

[26] ASTM C143-17, Standard Test Method for Slump of Hydraulic-Cement Concrete.

[27] ASTM C39/C39M-18, Standard Test Method for Compressive Strength of Cylindrical Concrete Specimens.

[28] ASTM C496/C496M-17, Standard Test Method for Splitting Tensile Strength of Cylindrical Concrete Specimens. 